\title{
Article \\ Brokerage in Cross-Border Mobility: Social Mechanisms and the (Re)Production of Social Inequalities
}

\author{
Thomas Faist \\ Faculty of Sociology, Bielefeld University, 33501 Bielefeld, Germany; E-Mail: thomas.faist@uni-bielefeld.de
}

Submitted: 24 November 2013 | In Revised Form: 25 August 2014 | Accepted: 31 October 2014 |

Published: 3 December 2014

\begin{abstract}
Brokerage is an essential yet understudied function in social life. In one of the classics in the field of sociology, Georg Simmel differentiated three types of the "third" which help to analyse brokerage: the disinterested mediator or arbitrator, tertius gaudens and divide et impera. Studies that conceptualise traffickers and smugglers as brokers are extremely rare. Scholars lack a typology which can serve as a basis for comparative research. To advance scholarship on brokerage this article seeks to develop a conceptual-typological matrix by setting out to explore three questions: Why does brokerage exist? What kind of social mechanism is brokerage? What are the implications of brokerage for social inequalities and equalities? The analysis concludes with the consequences of different types of brokerage for the (re)production of social inequalities.
\end{abstract}

\section{Keywords}

brokerage; inequality; migration; social mechanism

Issue

This article is part of a regular issue of Social Inclusion, edited by Professor Ulf R. Hedetoft (University of Copenhagen, Denmark).

(C) 2014 by the author; licensee Cogitatio (Lisbon, Portugal). This article is licensed under a Creative Commons Attribution 4.0 International License (CC BY).

\section{Introduction}

Conceptually, reference to ubiquitous migrant networks (Gold, 2005), social capital (Massey \& Aysa, 2005), or migration systems is not sufficient to account for how some of the reciprocal relationships between migrants and others who offer intermediary or brokerage services function. Any analysis in this area should include not only migrants and their networks but also (potential) employers, private individuals, and states (Krissman, 2005). Mechanismic explanations of these relationships have approached the problem by, for example, breaking down network effects into the three mechanisms of (1) exchange of information, (2) the norm of reciprocity, and (3) collective action of migrants (di Maggio \& Garip, 2012). These are very broad general mechanisms which are of importance in accounting for migration dynamics. Cutting across at least the first two of these mechanisms, if not all three, is brokerage, name- ly a third party connecting two actors. Network methodology has not systematically considered the figure of the "third" in processes of observation, translation, mediation, arbitration, rivalry, coalitions, and other elementary configurations of social life. Even less attention has been paid to the effects brokerage has on existing patterns of social (in)equality and new (in)equalities emerging from migration. Yet it is useful to study brokerage as a sort of glue of social life, and especially in the field of migration. This paper offers a conceptual sketch for a typology of brokerage in cross-border migration and outlines how to study the consequences brokerage has for social (in)equality.

Georg Simmel developed the sociology of the triad, which allows for three typical groupings of brokers which are not possible in dyads. When a third member enters a dyadic group consisting of ego and alter, various processes which previously could not take place then become possible. Simmel observed that the num- 
ber of parties to an interaction can affect its nature (Simmel, 1992, pp. 124-150). The "third" is so important because it is distinct from the dyad, and adds an element which is not present if we simply add a "fourth" and a "fifth". There is a qualitative difference between dyads and triads. The interaction between two people, a dyad, will be very different from that which is possible in a three-party relationship, or triad. This is key: within a dyadic relationship, each individual can maintain his or her role. When one party to the interaction is no longer interested in maintaining it, the relationship is over. As soon as another, third person is added, however, the situation and its possibilities change markedly, and group structures which are separate from and influence the individuals involved begin to emerge. Two of the people can form a group against the third; one person can become the mediator or the object of competition between the remaining two, and so on. Simmel saw the forms of these interactions as entailing similar options and strategies whether one was dealing with roommates in college, nation-states, or corporate groups.

The third is, in general, and in brokerage in particular, almost all-pervasive but is rarely theorized and highlighted as such. Simmel singled out three such processes (1992, pp. 124-150), although others have since been identified. ${ }^{1}$ First, a third member may play the role of mediator vis-à-vis the other two, helping, through his own impartiality, to moderate passions that threaten to tear the group apart. There are two types of non-partisan thirds: the one who bridges two parties-ego and alter-as a non-partisan mediator, ${ }^{2}$ and the one who makes a binding decision as an impartial arbitrator (e.g., between employers and unions). Second, the third may, alternately, act as a tertius gaudens-literally "the third who rejoices" - seeking to turn to her advantage a disagreement between the other two. In this case we find a configuration of reciprocal effects, in which a third party waits and sees and

\footnotetext{
${ }^{1}$ Simmel never claimed that there are only three types of the third, and we could certainly think of other types; consider, for example, the functions of brokerage which could be assumed by a translator or interpreter or by a scape goat. And in his excursus on "the stranger" Simmel not only addressed the marginality of the person who exists on the fringes of a group, but also describes how the stranger becomes an element of the life of the group when its members seek to confide in the stranger. The marginality of the stranger connotes a role that is in but not of the group. Thus the stranger can have detachment and objectivity and be sought after by the group members as an intermediary or as someone who can keep secrets (Simmel, 1992, pp. 764-771).

2 The simplest case of mediation is information flow. This does not create direct links between the parties on either side. The classical figure is the stock broker. As a result of brokerage in the wake of mediation, there is no direct contact between the two actors who are unconnected and for which the broker bridges the structural hole.
}

eventually draws an advantage out of the rivalry between ego and alter. Third, through a strategy of divide et impera (divide and rule), the third may intentionally create conflicts between the other two in order to attain a dominant position. The third rules in subverting the potentially more powerful coalition formed by the dyad. In doing so, she keeps apart ego and alter in the dyad by hierarchizing the relationship. Hierarchization of actors with respect to access to material and symbolic resources, social status or power already points to the potentially inequality-producing effects of brokerage. In a nutshell, brokers are not simply nodes in a network which bridge two yet unconnected nodes by just passing on information, but are parts of social patterns of (in)equalities. Inequalities are differences between groups of persons which are deemed by at least one party as unjust, in this case by the researcher; the reverse would be true for equalities.

In all three types of brokerage mentioned, social inequalities are at stake to induce or coerce other parties into acting in a certain way. In the first type, the nonpartisan mediator, the third can, by way of going in one or another direction, sustain the original power asymmetry, as is the case between striking immigrant workers and employers (regarding a strike of sans papiers in France, see Barron, Bory, Chauvin, Joumin, \& Tourette, 2011). With respect to the second type, it is obvious that the focus in terms of advantage shifts to the tertius gaudens who gains from observing the two (conflicting) parties who either vie, each individually, for his or her attention and support, or have conflicts of interest which the third waits to exploit. In the last type, divide and rule, the third party actively tries to instigate and rule over the two parties, ego and alter. In sum, the three types of third discussed by Simmel give us different perspectives on the (re)production of inequalities with respect to power, but also to resources and status.

Studying a social mechanism such as brokerage makes sense only in a clearly defined context (cf. Falleti \& Lynch, 2009). In international migration, this context is constituted primarily by the following constellation: there is a right to exit (one's country of residence) but there is no corresponding right to enter another state. ${ }^{3}$ This means that those migrants who get no legal access have an incentive to use the services of intermediaries who act as liaisons with consulates, traffickers, smugglers, recruitment agencies, etc. Needless to say, brokerage extends beyond the initial stage of cross-border migration and operates in transnational social spaces. A case in point is that of (former) international students who not only connect persons in places of origin and destination, but sometimes act as intermediaries across the globe (Bilecen \& Faist, 2014). Brokerage as a point of departure helps us to account for the selection

${ }^{3}$ This is even true for the largest internal migration system in the world, the hukou system in China. 
of migrants and their mobility, the adaptation of migrants, and the forging and maintaining of cross-border ties. So far, most research has related the concept of brokerage to very specific aspects-such as electoral politics (Koster, 2012), migration and trade (Galemba, 2012a), patronage relationships (Silverman, 1965), migration and passage (Spaan, 1994), and development cooperation (de Sardan, 2005, pp. 166-167, 173-178), to name a few selected examples. More specifically, the (historical) literature on brokerage in international migration, focusing on the nineteenth-century movement from Europe to the Americas and within Europereferencing key terms such as indentured labour, redemption system, transit migration, people smuggler, etc. - mentions the crucial functions of brokers but usually does not place brokerage in the broader context of political, legal and economic conditions (Moch, 1992; but see McKeown, 2008). There is thus a need to arrive at a conceptual-typological matrix.

Not all third parties or those taking over intermediary functions are defined here as brokers. Silverman argues that the functions mediators are concerned with must be both critical and exclusive (Silverman, 1965, p. 173). While critical refers to the notion of direct importance to the basic structures of either or both social groups or formations, exclusivity means that the link between the social entities must be made through the mediators. Thus, the number of roles for mediators is limited. Since intermediaries are persons who provide contact between two entities or levels but do not necessarily fulfil the two above mentioned criteria, Silverman distinguishes between the broader category intermediary, and the special type of intermediaries that are mediators. For clarity I use the term broker instead of mediator in order to capture broader types of function and status, and to distinguish from Simmel's terminology in which mediator is just one type of the third.

Brokerage as a social mechanism needs to be systematized for two reasons. First, brokerage helps to conceptualize the broader infrastructure that makes spatial mobility across borders (sometimes also within-for example, China) possible in the first place, as well as adaptation and maintaining ties across borders. Second, a brokerage perspective helps to break down unhelpful dichotomies. Very importantly, we cannot assume a priori that migrant and migration networks are characterized by altruism and brokerage by profitorientation. As previous studies have suggested, profit, on the one hand, and trust, on the other hand, "run hand-in-hand in between brokers and migrants, and distinctions between them are often impossible to sustain in practice" (Lindquist, Biao, \& Yeoh, 2012, p. 9). Going further, the analysis helps us to capture empirically the processes cutting across state and market, regular and irregular, formal and informal boundaries; see, for instance, political brokerage in a slum in Brazil (Koster,
2012). In this latter example, community leaders in Recife frequently occupy formal positions, such as presidents of grassroots organizations or representatives on local consultative bodies, which often contributes to their reputation as leaders. Such close intersections between formal and informal positions have also been observed in the topic studied here, migration brokers (Alpes, 2013b, p. 15). The informal practice of brokerage is often strongly connected to brokers' formal positions. Brokers who bridge formal and informal positions are to be found in numerous contexts. Take the intermediaries who act in the function of linking clients and bureaucracies-an example would be political "fixers" in India (Reddy \& Haragopal, 1985; see also Jaffe, 2013).

Drawing on examples ranging from nineteenthcentury Europe to twenty-first-century South and Southeast Asia, the remainder of this paper sets out to explore three questions: (1) How can brokerage be conceptualized as a social mechanism and what kind of social mechanism is it? (2) Why does brokerage exist? (3) What are the implications of different types of brokerage for social inequalities and equalities?

\section{Brokerage as a Social Mechanism and Social (In)Equalities}

Since labour migration and other forms of cross-border mobility constitute an adaptive response to social risks and related inequalities of opportunity on the part of the movers, a conceptual approach to brokerage should be open to the idea that it can at the same time perpetuate old inequalities and create new ones. It should also be borne in mind that cross-border mobility is the outcome of socio-economic, cultural and political transformation and related inequalities (e.g. income inequalities between world regions and within those regions), which are in some cases even on the increase. While migration is indeed one of the oldest means of humankind to combat poverty (Galbraith, 1979, p. 7), and at the individual or family ${ }^{4}$ level geographical mobility may indeed be a successful strategy for gaining employment and social protection (Goldin, Cameron, \& Balarajan, 2011), its consequences may

\footnotetext{
${ }^{4}$ The family, or better, kinship is a type of organization in which the third is still specific; reciprocity is general across many members who usually know each other and reciprocate in various fields - from health care to emotional support. By contrast, the state is a type of social organization in which the third is specific; reciprocity is thus more specifically geared toward selected realms, e.g. the contract between generations in certain retirement systems. With respect to both family and the state, brokerage can be conceptualized at the level of agency but also as a structural feature built into certain types of social organization. As to the relation between structure and agency, Karl Marx cogently remarked in the $18^{\text {th }}$ Brumaire of Louis Bonaparte, people make their own history, but not under conditions of their own choosing.
} 
(re)produce inequalities. For example, while family members of migrants in the regions of origin may receive financial remittances, those without kin abroad usually do not-and thus the relative distance in income and wealth between the two categories may increase (Lipton, 1980).

To ask how exactly brokerage works means studying social mechanisms. The term "social mechanism" refers to recurring actions and events, and links identifiable initial conditions with specific results; it is a helpful concept for identifying processes that generate (in)equalities (McAdam, Tarrow, \& Tilly, 2001, p. 24). We move from an initial condition I (e.g. the wish to migrate across borders, or to adapt to social life in a country of destination) to an outcome $\mathrm{O}$ (e.g. successful adaptation, such as finding housing, child care, employment) by way of specifying the processes, that is, the mechanism(s) $M$ involved between I and $O$ : I-MO. By studying brokerage as a social mechanism we contribute substantially to the understanding of the (re)production of (in)equalities in social life. After all, brokerage may significantly affect the social position and life chances of those agents involved.

Overall, brokerage needs to be disaggregated as a social mechanism into sub-mechanisms to be of use. This crucial task is nicely illustrated in Pamela Oliver's criticism of the seminal work by McAdams et al. (2001) on collective action:

The mechanism...that comes up most often [in the volume] is called "brokerage", a term borrowed from network theory...to refer to people who connect previously unconnected groups, and the book stresses its importance in virtually every episode. But the nature of this brokerage varies tremendously from case to case. For the Mau Mau, it is a semi-planned recruitment strategy that is pretty similar to a diffusion process: particular groups are recruited and converted, and then sent out as recruiters of others. Taxi-drivers are "brokers" here because they meet a lot of people and can thus provide communication bridges to new groups. But in other situations, e.g., the development of the Italian state, the brokers are more in line with the usual meaning of the term, people who help parties with partially conflicting interests find a mutually agreeable bargain. Mediating a bargain over interests between extant groups and providing a communication link between previously unconnected individuals are not the same process, and simply calling them both "brokerage" does little to advance understandings. (Oliver, 2003, pp. 121-122)

Nonetheless, network methodology is a useful point of departure. Along with others, such as exploitation (Marx), opportunity hoarding (Tilly, 1998), social closure (Weber, 1968), or hierarchization (Therborn,
2006), brokerage is a social mechanism - a sort of social master mechanism. By and large, brokerage means that third parties, that is, brokers, bridge "structural holes" (Burt, 1992; see also Gould \& Fernandez Roberto, 1989). Such holes exist when there are no direct ties between actors (also called "nodes"). In Burt's understanding, brokers then act as a third party that arranges for the connection -in order to facilitate access to valued resources, such as travel documents, papers to work in another country, civil and social rights, or material resources. Brokerage bridges those who are not directly connected to each other in a situation where the parties are connected to a focal actor-the broker-but not to one another. ${ }^{5}$ Yet the function of a broker bridging structural holes is not wide enough to understand brokerage in social processes. The two parties may very well know each other. Also, the third, in Simmel's sense, may not be simply a disinterested mediator or arbitrator but an involved party, a tertius gaudens or a function of divide and rule. Simmel's typology offers a broader understanding of different constellations of brokerage.

Brokerage is a tool that helps to account for unequal outcomes. Services of a smuggler, a trafficker, or a labour recruiter across international borders may come at a cost; but not doing so also carries costs, namely of missed opportunities for better life chances. Throughout the nineteenth century, for example, many Indian and Chinese labourers signed debt contracts, agreeing to repay their transportation costs from wages earned in their countries of destination, for example the United States. This kind of indenture could result in relatively voluntary, short-term wage labour, but could also cross over into unfree and bonded labour (Bush, 2000). Brokerage is also closely connected to what could be called modern slavery, such as trafficking people to be held in debt bondage. Modern slave owners do not "own" the bodies, which are nowadays considered disposable (Bales, 1999), and thus do not take care of them-as in some forms of slavery in historical times.

Social inequalities here refer to the distribution of resources (material and symbolic), social status and power considered unjust by one of the parties involved

\footnotetext{
${ }^{5}$ Take the case of two hitherto unconnected actors brought together in catalyst brokerage. Through brokerage, the two parties on either side of the broker do get to know each other, the two parties strike up a relationship. This type of brokerage is well known from research on social relations in hiring. Mark Granovetter's (1973) analysis pointed out the importance of "weak ties", that is, that social ties outside one's immediate frame of social ties (strong ties) can be more beneficial in opening up job opportunities. Granovetter concluded that strong ties may be too redundant to bring new and additional information. Of course, the strength of the weak ties phenomenon is predicated on the assumption that resources inherent in strong ties are not sufficient.
} 
or by the researcher(s). With respect to social (in)equalities, two sets of evaluations matter: objective evaluations (from the point of view of the researcher) as well as subjective perceptions (from the point of view of the persons concerned). For migrants the perceptions of (in)equalities regarding resources and status could relate to regions of emigration, regions of immigration, or both. The units of analysis and of reference are empirical matters and depend on the question(s) asked. These units could be family or kinship networks, village or professional. This approach is appropriate because cross-border transactions may take place on different levels, such as the family, friendship cliques, business networks, local communities, or organizations, and it is through the very practice itself that agents constitute these scales in the first place.

\section{Why Does Brokerage Exist?}

Simmel indicated that one of the characteristics of "the third" is the ambiguity of the broker's role. Brokerage involves issues of connectivity between persons and groups, as well as trust. Research on international migration is a prime example of a field in which the importance of brokerage is highlighted because in the broadest sense brokerage acts to reduce transaction costs, that is, the costs necessary to overcome boundaries. Such boundaries are met along the way through the various stages of migration: obtaining a visa to cross national borders, crossing borders back and forth without a visa (undocumented border-crossing), adapting to the new country upon arrival-for example by finding housing, work, and child care, as well as adapting for the longer term. Brokerage operates to bridge divides between newcomers and established groups in the place of settlement. Yet brokerage is not only of importance in migration processes from $A$ to $B$ but also in processes of return migration, onward movement to yet more destinations, or circular mobility across borders.

It is usually only after brokerage has been provided to work abroad that emigration becomes initiated in an institutionalized way-going beyond individual and small-scale networks (see, for example, Minghuan, 2012, p. 218; Morawska, 2007). As migration control and management have become more sophisticated, the demand for brokers is ominpresent at all levels, seen, for example, in cases such as the Asia-Pacific migration systems. This trend is particularly salient for large parts of Asia, where a number of researchers have noted a dramatic increase in the number of private recruitment agencies operating as brokers at the centre of a new transnational migration regime (Lindquist et al., 2012, p. 8). One may argue that the emergence of "circular migration" at the top of the international policy agenda as the management form of the future represents an important manifestation of these formalization processes (Lindquist et al., 2012, p. 12).
Clearly, in the case of international migration, brokerage may have definite advantages for various parties involved: information and goods travel much faster and more smoothly via brokers, and the costs involved for migrants may be much lower than through organizational channels proper. Consider the practice of remittances; if a migrant wishes to transf er money from Manchester to a village in northwest Pakistan, the transaction costs of sending it via Western Union or MoneyGram are usually higher than through informal networks, such as hawala or hundi-the long-standing system of transfer around the Indian Ocean. The transfer involves brokers such as an individual in Manchester, businesspeople in Dubai and intermediaries in Pakistan. Such informal practices, however, can also result in unintended negative consequences for migrants (Passas, 1994). This becomes visible, for example, when little information is available on the security of transfers organized by private individuals. Also, brokerage has been known to result in debt bondage and "modern slavery" (O'Connell Davidson, 2013). Brokerage may thus even be detrimental to the pursuit of a better life abroad. Therefore, the very idea that brokerage simply lubricates the machines of cross-border mobility may be based on wrong assumptions. For example, economists have held that the function of brokers is to bridge information gaps between the demand and supply of workers, and once the gap narrows, brokers will tend to disappear to reduce transaction costs. However, this is an assumption which does not travel very far, since brokerage is not simply a market affair.

Brokerage cannot be explained simply by the fact that official, formal (e.g., state) channels for migration need to be lubricated by informal practices. This would be an inaccurate description of such brokerage processes. First, what migrants usually care about most is whether the dream of migration as a strategy to enhance life chances can be realized, rather than whether the mechanism of cross-border movement is legal or not (e.g., Alpes, 2013c, p. 9; Minghuan, 2012, on the case of China in historical perspective). Second, migrants care whether brokers operate on a secure formal basis. As studies on local-national mediation in the 1950s and 1960s showed convincingly, certain local wielders of power could act as regional patrons and mediators between various levels of government precisely because they occupied formal positions that formed the links between local and national systems (Wolf, 1956, on Mexico; Silverman, 1965, p. 180, on Italy). It was the control of the brokerage function which was the primary source for their ability to exert patronage, that is, deliver favors to the local populace in exchange for resources such as votes at election times.

We have to look at how international migration is really operating. Ever since their inception, modern states-for example, in Europe since the sixteenth century (cf. Lucassen \& Lucassen, 2014)-have sought to 
rein in mobility across their borders and control it tightly. In doing so, states have constantly recreated the need for brokerage. Immigration and emigration policies create the very "holes" which brokerage is required to overcome. With respect to migration, border control and internal boundaries (e.g. certification in certain trades to be eligible to practice) are functions of states. Since modern states engage in multiple functions, some of these may be at odds with each otherand this is why brokerage becomes at times so important both for migrants trying to navigate the still unknown seas of their countries of destination, and for states to bridge principles which cannot be reconciled on a practical level. For example, brokerage may arise at the interstices of the state's function of asserting migration control, on the one hand, and its provision of a modicum of social welfare, on the other. There is a tension or even dilemma created by these two functions: the state abstains from expelling asylum seekers whose requests have been denied, but does not offer a secure legalization of their status. At the same time the state has to provide shelter for those in need-as evidenced in the case of "welfare hotels" in Paris, for example. On the one hand, the state is interested in effective migration control and thus limiting the number of those on its territory who have no regular papers; on the other hand, the state has some obligation to observe basic human rights, such as fundamental social rights to housing even for those who have no regular papers, the sans papiers (de Wenden, 2010). Caught in this dilemma, the state, claiming to exert monopoly of power over a territory and membership and to be the sole legitimate actor in this field, tends to confer authority onto other actors. In this case, state authorities may allow civil society organizations to take care of persons in need and house them in shelters as they see fit (Alpes 2013a). Since migrant families whose request for asylum has been denied also face homelessness, they are-under certain conditions (that they be single mothers with small children)-also admitted. In allowing only single mothers with small children to obtain such accommodation, and requiring them to live separately from their partners, the state's control function becomes apparent in a second way. The state not only controls legal status but also exerts control over social and moral behaviour through the intersection of formal practices (e.g. allotment of rooms) and informal practices (e.g. brokers deciding on who can receive visitors overnight). In this way, states provide the frames for meta-norms, in which specific norms may play out on a lower level.

Nonetheless, states also constantly seek to ensure that they are considered the legitimate wielder of power over borders. One way is through criminalizing other agents active in organizing the crossing of borders. It is crucial to understand the conditions in which states delegitimize certain forms of brokerage. After all, states seek to control who is involved in the crossing of boundaries, not only of the state's physical borders but also of membership (legal status) which gives entitlement to certain civil but above all political and social rights (Hollifield, Martin, \& Orrenius, 2013). States thus try to criminalize certain types of brokers but not others. Most often it is the traffickers and smugglers who are criminalized. However, much less criminalization occurs in areas in which brokers are not challenging the monopoly over violence or market regulation, e.g., in social welfare provision. In their effort to delegitimize certain agents not authorized by the state, state officials and agencies constitute the migrant as a vulnerable subject who is the victim of unscrupulous criminal traffickers. Most instrumental in this exercise are not only states but international organizations, which discovered migration after the end of the Cold War as a field to be regulated. In the search for new fields of activities, international organizations such as the International Organization for Migration (IOM) have enacted many programs in their fight against traffickers in the context of illegal migration (Pécoud \& Geiger, 2013).

States have an interest in framing market actors as fundamentally different, but in practice there might be more parallels than expected (Alpes, 2013a, p. 146): for example, the framing of money issues-state authorities demand a "fee", private agents ask for a "price" serves as an instrument of boundary-making between state and non-state actors within migration control. The disciplinary tactics of constructing mediation by state actors as de facto non-mediation and of framing monetary flows differently contribute substantially to the construction of state practices as supposedly disinterested and transparent, while non-state actors are sometimes stigmatized as profit-oriented criminals. The counter-image to brokerage as illegal is "illegal but licit": though emigration as well as immigration states combat smuggling and irregular migration, many migrants and their families see it as a moral act to facilitate migration (Sanchez, 2013). We may even think of a sort of moral economy of brokerage. This state of affairs has resulted in the creation of dynamic "regimes of permissiveness" and thus a thriving migration industry (Kalir \& Sur, 2012). It is noteworthy that from the perspective of mobile persons and their significant others, such as families, there is not necessarily a contradiction between the profit orientation of brokers on the one hand and social trust on the other. Still, one should not overgeneralize these observations-there are many brokerage processes which are devoid of any kind of trust, involving truly criminal networks of brokers engaged in the drug trade and other violent illegal business activities (see the superb account on crossing the Sahara into Italy by Gatti, 2011).

The criminalization of private brokers by states can be traced as far back as the nineteenth century (McKe- 
own, 2012). By the late nineteenth century brokers and middlemen began to be increasingly demonized as the source of migration troubles encountered by labour migrants. In the mass media and government statements alike, brokers then were depicted by less than flattering terms such as padrones, crimps, smugglers, and coyotes. Immigration laws in general and laws to regulate brokers in particular also relegated many of the brokerage activities of private agents into the realm of illegality. This stigmatization of brokers came hand-in-hand with the emerging ideal of the "free" migrant as a self-motivated individual. Brokers were thought to interfere with the freedom that was believed to be the hallmark of a genuine migrant. These processes went on, even as brokers found new methods to assist migrants in negotiating the legal requirements. In a way, what was touted as modernization of immigration policies, such as an emphasis on ablebodied labour (human capital) along ethnic and racial lines, which acted effectively in exclusionary ways (e.g., the Chinese Exclusion Act of 1881 and US legislation after World War One), also disconnected nodes and recreated the need for brokerage (cf. Ferguson, 1999, p. 236). Not surprisingly, the demonization of brokers as criminals en tout court continues to draw attention away from employers of migrants and broader structural processes and onto brokers as explanations for the inequalities involved in international migration.

The state's constitution of legitimate and legal brokerage activity vs. criminal activity as a binary is only one constellation. Some civil society actors are not that easily criminalized. One example is churches in many immigration states who offer sanctuary or "church asylum" to asylum seekers whose claims have been rejected by the respective state authorities. In this case, secular and church law are at odds with each other. This opens up space for brokerage on the part of parish communities or congregations, being not of the church (and the state) but in it (Lippert, 2005, on Canada). Practices of sanctuary are genuine in their enabling effects, evinced in the way these practices have been binding local sanctuary providers together in common pragmatic cause. There have been instances in which sanctuary has merged the concerns of sanctuary providers, refugee advocates, and immigration authorities. In this case, according to Simmel, brokerage dissolves into coalition.

It is important to note also that states may act as brokers themselves. States regulate agents who are involved in organizing access to employment. As we know, markets of fictitious commodities such as labour are built in no small degree by states themselves, and exchange relations function in a context set by state authorities, among others (Polanyi, 1944). For example, the Philippine state engages in training nurses and care workers to be sent abroad. This active role of the state does not end with job training but extends-in some instances at least-to dealing with legal problems faced by Filipino/a workers in foreign countries (Lindio-McGovern, 2013). Another case in point is China (PRC) in the early 1980s (Minghuan, 2012, pp. 214215): in the course of cautiously opening up the country for emigration a bit after the late 1970s-for example, by allowing family members to join others abroad-the Chinese state founded a semi-governmental institution; later named the International Economic and Technical Cooperation Company, or XIETC Company. This company held a monopoly on labour brokerage in the province of Xiamen until, during the 1990s, the field was taken over mostly by private agents-still supervised in the last instance by state authorities.

So far, the analysis has not considered the fact that brokerage takes place with various types of actors. These can be multinational corporations in the business of border control and deportation; agencies and companies which facilitate access to legal and illegal forms of migration (recruitment agencies which cater to the needs of labor markets); clandestine actors which include trafficking and smuggling networks (which might offer marrying schemes, or collaborate with corrupt border agents); and NGOs, humanitarian organizations and migrant associations which are sometimes driven by more than just material gain (Gammeltoft-Hansen \& Nyberg Sørensen, 2013). Among these different types of brokers, hierarchies can be discerned. In the Chinese context in the 1990s, for example, a three-tiered system seems to have operated: (1) a small group of privileged brokers at the top, who usually held legal status to stay abroad: they were able to issue documents and bribe officials; (2) a middle group who often sat in an officially registered company in the emigration country: these were mostly institutionalized brokers, authorized to engage in labour exportation; (3) and finally, at the bottom, there were locals who acted individually, for example by being connected to relatives abroad (Minghuan, 2012, p. 221). How these levels are interrelated is poorly understood; that is, the processes of hierarchization among brokers have not yet been sufficiently explored.

On all these (hierarchical) levels, which intersect and interact with state agencies, brokerage often occurs at the interstices of formal and informal practices through all stages of the migration process, for example, between migrant groups and state bureaucracies. There is no formal or informal sector as such, but there are formal practices and informal practices, often within a single organization. Moreover, organizations-and with respect to administration, the state can also be seen as a set of organizations-always provide space for informal practices; without such informal practices, (formal) organizations would not be able to function.

Shifting the perspective from the brokers themselves to migrants, it should be noted that the type of brokerage needed by international migrants depends 
on legal status (Sredanovic, 2013); for example, migrants in the early stages of immigration in a country of destination may need ties to other, pioneer migrants to set them up with the basic necessities of life; later on, once they have adapted somewhat, they may need access to state bureaucracies to legalize their status; in this second stage, brokers from support organizations in civil society may become essential, e.g. representatives or persons working for unions, churches, or human rights organizations.

\section{What Are the Implications for Social Inequalities and Equalities?}

Official intergovernmental documents often portray brokers in a negative way. Brokers are vilified: they allegedly distort markets, engage in corruption, and violate and infringe upon human rights (e.g., GCIM, 2005, p. 70). However, a review of the literature suggests that it is usually not clear whether it is the brokers who are instrumental in bringing about this outcome, or other parties. Also, the mechanisms by which inequalities are produced are not clear. The time is ripe, therefore, to generate a typology of types of brokerage and of the mechanisms operative within these types. The following constitutes a first step toward a typology of brokerage.

Brokerage constitutes a noteworthy social mechanism because the outcome is ambiguous due to, among other things, the broker's role. Brokerage can result in dependency and exploitation but also in increased capacities for the beneficiaries. It is the broker's function which makes for complex relations of dependency and power asymmetries between the parties involved. Other social mechanisms could also be involved, preceding and following brokerage, such as social exclusion/inclusion, exploitation/redistribution, racialization/affirmative action, etc., since brokers offer resources which may enable or hinder spatial, and eventually social, mobility, adaptation to new environments and the exchange of ideas.

Though there are many types of brokers imaginable, I restrict the typology to three-two classical ones derived from Simmel, and an additional one-partisan arbitrator (Table 1). I do not discuss Simmel's first type of "the third", namely the non-partisan mediator and arbitrator. The non-partisan who tries to mediate (or even bindingly arbitrate) serves the whole. Yet that type does not seem to be visible in migration brokerage. Instead, I discuss partisan arbitration or even advocacy. Brokerage in migration is usually partisan, seeking to serve the role of migrants, or the state, and the brokers themselves. Therefore, it can be called a limiting case because Simmel is quite right in arguing that the partisanship of the third-if it leads the two original parties to collude and form a dyad-is the end of brokerage. However, in areas such as international migration, advocates who act as brokers may take sides but, as we have already encountered in the case of NGOs, still maintain their relations with the other party, such as the state. Consider, for example, NGOs who engage in delivering services to new immigrants. Such NGOs side with immigrants but are often financially dependent on state agencies. And even if that does not apply, they need to entertain channels of communication with state agencies to effectively serve their newcomer clients.

Table 1. Types of brokerage and mechanisms of inequality.

\begin{tabular}{lll}
\hline $\begin{array}{l}\text { Types of } \\
\text { brokerage }\end{array}$ & $\begin{array}{l}\text { Sub-mechanisms } \\
\text { relevant for } \\
\text { inequalities and } \\
\text { equalities } \\
\text { (examples) }\end{array}$ & Examples \\
\hline $\begin{array}{l}\text { Partisan } \\
\text { arbitration }\end{array}$ & $\begin{array}{l}\text { Solidarity } \\
\text { Diffusion }\end{array}$ & $\begin{array}{l}\text { Social movement } \\
\text { organizations; } \\
\text { networks of activists }\end{array}$ \\
$\begin{array}{l}\text { Tertius } \\
\text { gaudens }\end{array}$ & $\begin{array}{l}\text { Benching } \\
\text { Opportunity } \\
\text { hoarding }\end{array}$ & $\begin{array}{l}\text { Recruitment agencies } \\
\text { (body shops) }\end{array}$ \\
& Altruism & \\
$\begin{array}{l}\text { Divide et } \\
\text { impera }\end{array}$ & $\begin{array}{l}\text { Exploitation } \\
\text { Hierarchization }\end{array}$ & $\begin{array}{l}\text { Middleman minorities } \\
\text { in (former) colonies; } \\
\text { traders; } \\
\text { Domination }\end{array}$ \\
& & Démarcheurs \\
\hline
\end{tabular}

\subsection{Partisan Arbitration}

While states themselves may act as brokers, and while states often cast private actors as illegal arbitrators, there are civil society actors, such as NGOs, who display legitimate social and humanitarian justifications for their participation in the migration industry, in particular what has been called the "rescue industry" (Gammeltoft-Hansen \& Nyberg Sørensen, 2013). Such NGOs, which may be active with respect to international refugees, base their activities and practices on human rights. In doing so, they add a third dimension, namely solidarity, to the control and monopoly power sought by the state, and facilitation promised by private, commercially-oriented agents.

At the level of civil society, solidarity functions as the main mechanism underlying this type of brokerage. This is evidenced, for example, when social movement groups provide space for issues to be deliberated in the public sphere, such as the initiative "No more deaths on the border", which has been operative in Arizona for the past ten years (Feldman, 2013). This movement has raised attention to the deleterious effects of increased securitization on the Mexican-US border; not only effecting border-crossers but also for those living in the borderlands. One may even think of this initiative as a 
kind of brokerage between migrants and the border population on the one hand, which both suffer from transgressive border guard practices, and the political system on the other. In this way it is not simply a case of advocacy but also a sign of solidarity with migrants.

Historically, there were numerous civil society associations active in the US dealing with immigrants in the late nineteenth and early twentieth centuries. On Ellis Island, voluntary organizations such as St. Raphael's Society, the Society for the Protection of Italian Immigrants, and the Women's Home Missionary Society took care of immigrants fresh off the boat. They helped them with the official procedures and offered services for adapting to the new environment. All these organizations were required to have official legitimation for their activities by federal state authorities. Again, as in the case of the "welfare hotels" mentioned before, brokerage thus arose at the interstices of the function of the state for migration control, on the one hand, and ensuring a modicum of social welfare, on the other. The state was a crucial actor conferring authority to other actors; in this case, civil society organizations.

A case in point for solidarity on the part of charitable organizations, and in this particular case one which formed out of the immigration experience, is the Hebrew Immigrant Aid Society (HIAS) in New York. As one historian described HIAS' activities in the early twentieth century:

The activities of HIAS workers suggest how such ethnic societies served their own. Men and women wearing blue caps embroidered with the letters HIAS in Yiddish met the ferryboats landing at Ellis Island. They distributed to Jewish immigrants information sheets printed in Yiddish which explained the inspection procedures. They eased the fears of the anxious with warm smiles and advice on how to answer questions....Should one lie or tell the truth? Should one claim poverty or show one's money? Would the immigrant inspectors expect bribes such as those Russian officials had demanded? Society agents urged the immigrants to be honest and interceded with immigration officials so that the nervous, confused immigrant might have adequate opportunity to provide the correct information....Newspapers would be brought by HIAS workers to Ellis Island on the ferry and all-night staff members would work to match each immigrant to a job advertisement. (Kraut, 1982, pp. 61-62)

There are also indirect consequences of the practices of civil society actors which can be classified as brokerage: in the Netherlands, for example, for two decades single and divorced Dutch fathers and EU citizens mobilized human rights law to reunite with their children. Eventually, not only did they benefit from the successful mobilization of European human rights law, but so also did single and divorced mothers from outside the EU who did not hold Dutch citizenship (Van Walsum, 2009). This case already suggests that brokerage is to be understood not only in the sense of agency-although it is of the agents' making-but also as a structural feature: the gains made by more powerful actors filtered down to less powerful ones via the practices of law. We can speak of a diffusion effect. Like solidarity, this is not an inequalityproducing but an equality-generating mechanism.

The boundaries between partisan arbitrage in civil society and in large kinship networks are fluid: since families or kinship groups more generally are based primarily on the mechanism of generalized reciprocity, brokerage is also built into this mechanism. Nonetheless, nuclear families at least cannot really be seen as a brokerage system-close ties tend to yield too much redundant information (cf. Granovetter, 1973). Yet wider kinship systems could be a limiting case. An example is the interaction of state visa systems with kinship reciprocities in providing access to visas in Gambia for young men of Soninke ethnic groups (Gaibazzi, 2013). There are two crucial parameters involved in providing their access to visas. First, there is the family group in which relatives, mostly the elders, decide which of the young men are bound for Europe. The link is usually a relative who has already settled in a European country. Family relations are decisive; for example, solidarity tends to be higher among children of the same father and mother than of the same father and a different mother. Second, relatives usually also facilitate access to intermediaries in the migration industry who help potential migrants obtain legal documents, such as a passport or a birth certificate.

\subsection{Tertius Gaudens}

Formally speaking, the specific constellation of tertius gaudens means that there is a divergence of interest of two elements (actors) out of which the third draws an advantage. This does not mean that there is an open conflict between these two elements, only that there is a sort of perceived difference between the two (Simmel, 1992, pp. 139-140). Such differences between two parties may be logics of action which exclude each other. A historical example dating back to the late nineteenth and early twentieth centuries is that of the state of Prussia in recruiting agricultural labour, in which political and economic interests were in tension. Politically, the recruitment of such labour in Eastern Europe constituted a security risk in the eyes of the Prussian authorities. Yet, economically, such migrant labour was sought after by the agricultural-military elites who served as the political backbone of the Prussian state, among them the Junkers. The state itself became a broker through a central agency, the so-called Feldarbeiterzentrale, instituted in 1907. Increased state control notwithstanding, the agency cooperated with pri- 
vate recruiters in Eastern Europe.

In order to benefit from his or her position, the tertius gaudens does not need to be much more powerful than the two other parties. His or her ability to derive advantages is determined by the constellation of power among the two remaining agents (Simmel, 1992, p. 137). It is decisive that the support of one of the two parties by the broker tips the the scales in either way. To take an example from historical migration research, commercially active private agents instigated labourers (Preußengänger) to breach their contracts, as a way to derive premiums twice since the agent could hold recruiters accountable. On the other hand, the private agents cooperated with agricultural employers by keeping part of the wages in order to avoid breaches of contract. As a crucial prerequisite to playing it both ways the brokers need to speak the "language" of both sides, such as-in development contexts-between the target population and the development institutions, speaking the languages not only literally but also with respect to moral, ideological and other significant features (de Sardan, 2005, on "development brokers").

The advantaged position of the tertius gaudens disappears at the moment the two other parties form a unit, that is, the constellation of three (the triad) reverts into a dyad. Such a development may occur without a fusion of interests in that the object of strife simply disappears (Simmel, 1992, p. 141). A case in point is the right of entry into another state, which is an extension of the right to exit. This rare right was achieved, for example, in the early 2000s by the eastward expansion of the European Union (EU). There was simply no need for migration brokerage anymore.

The implications of tertius gaudens for social inequalities can be studied fruitfully in the case of labour management, which deals with the control of labour in the workplace and beyond. International migration in a global context then raises the question how various sorts of labour can be managed. Biao (2007) studied the global IT market with a specific focus on what are termed skilled workers from India (e.g., software engineers) and on specific kinds of recruitment agencies called "body shops". These agencies recruit IT workers as project-based labour, mainly from India. The body shops manage workers on behalf of employers, and are sometimes employers themselves, and thus offer services which range from sponsoring workers' temporary work visas to paying their salaries and arranging for accommodation. One may interpret Biao's case study as including at least two sets of overlapping brokerage: body shops act as the broker between employers and workers (e.g., wages, terms of engagement), and between employers and states (e.g., visa). It is thus a set of relationships involving four major parties, the body shops, the employers, the workers and the state authorities.

Since body shops as brokers ensure that workers and employers do not enter into any direct relationships, employees can be retrenched at any time. These migrant workers thus carry the brunt of the costs and the risks (see Kuptsch, 2006, on "merchants of labour" more generally). Body shop operators either place IT workers out to another employer, or put them on the bench to await further placement. The main instrument here is called "benching", which makes sure that a flexible labour market can be institutionalized and maintained (Biao, 2007, p. 22). In a nutshell, body shops externalize costs to workers so that there is not only no negative impact on the employer in the supply of workers but what is more, there is a ready supply of docile workers. In addition, benching also helps to handle labour management free from obligations under labour laws, which eases exploitation of workers by employers. Inequalities among the workers, in turn, at the surface, run along lines of ethnicity; for example, employers in the US put workers to certain tasks for the very fact that they are Indian. Yet the ethnicization of body shopping has little to do with ethnicity as it is usually understood, since Indians of multiple religious backgrounds (Hindus, Muslims, Sikhs, etc.) are treated the same by body shop operators. Instead, the ethnicization of workers enables body-shop operators to get around state regulations by appealing to the workers' complicity and to ensure compliance from the workers whose visas they sponsored (Biao, 2007, pp. 7-8). Furthermore, entrepreneur-aspiring IT workers often use body shopping as an entry point for acting as subagents and eventually become body shop operators themselves. In so doing, body shopping as a business using ethnicity as a heterogeneity relevant for inequalities is further reproduced. The concepts of individualization and professionalism deployed by Indian IT workers contribute to the justification of hierarchic differentiation among workers with respect to renumeration and working conditions as natural. Individualization justifies hierarchies among workers, based on the assumption-shared by the workers-that success depends solely on merit. Very importantly, this helps to ensure body shops' control over IT workers.

Going beyond the brokerage relationships and viewing these processes in a transnational perspective, the low-tier informal sector effectively siphons off local resources in India, embodied in the labour force, and in so doing provides not only cheap and skilled labour to the overseas sector, but also delivers, when small players move up, finance capital to the higher sector in India and destination countries such as the US, Australia and the UK (Biao, 2007, p. 112). Transnationalization allows not only for new cross-border links of capital and transfer of wealth but also makes possible the reproduction of social inequalities. The "war for IT talent" can only be waged because there is a huge supply of willing IT labour in India; this in itself may not be problematic, as there may be circulation of labour-thus 
brain drain is also partly brain circulation. However, investments come from below, made by IT workers who become entrepreneurs not only of themselves but of others, and these investments are for the most part made not in India but abroad in the US, Australia, the UK, etc. These patterns help to recreate inequalities between the regions involved.

When viewed in comparative perspective, the system of body shopping stands-with respect to its effects on social inequalities between workers and employers and among workers-somewhere in between the guest-worker system of Europe in the 1960s at one end of the spectrum and project workers and contract labourers in the Middle East on the other end. In Europe, guest workers were employed on nominally the same social rights basis as non-migrant labour with respect to unemployment insurance, health insurance and pensions, albeit in 3D positions ("dirty, dangerous, demeaning"). This constellation allowed for a rough legal parity between native and immigrant workers with respect to socio-economic rights. In contract and project-tied work for so-called low-skilled labour traveling on the migration highways from, for example, South Asia to the Middle Eastern Gulf states, there are reports of abuse (ILO, 2012). Clearly, project-based and contract labour in many Middle Eastern countries depend on the legal disadvantages of migrant workers vis-à-vis the native workforce which is sometimes even in the minority, numerically speaking. As is well documented, the differences in legal status also translate into inferior working conditions (Abella, 1995). In short, from the point of view of immigrant workers, the hierarchy of preference with respect to legal status would be thus: at the top is the guest worker system of Europe in the 1960s and 1970s, in the middle the globalized system of body shops operating out of India since the 1990s, and at the bottom the project-tied labour schemes in the Middle East.

Entire local communities engage in brokerage and, at first glance, enjoy the status as a collective tertius gaudens. Nonetheless, not all community members benefit equally. Rebecca Galemba describes how residents living on the Mexico-Guatemala border strategically use their location at a clandestine border-crossing road to make 'business' (Galemba, 2012a). Since the late 1990s, residents have been successful in prohibiting the entrance of state officials to the extent that the road is now considered to be "free". The Zapatista uprising in the Chiapas region in 1994, other peasant and social movements, and the increasing presence of gangs and cartels reinforced views on the part of the Mexican state that the social, political, physical and financial costs of patrolling the border outweighed the predicted amounts of contraband. Since migrant or borderland networks as such cannot explain how people and goods are moved, Galemba "focuses on crossborder intermediaries and smugglers, truckers, and the smaller-scale extra-legal activities of residents who struggle to maintain their livelihoods in a local economy revolving around contraband" (Galemba, 2012a, p. 3).

Two categorizations matter with respect to inequalities: First, there are those who participate in the contraband economy and those who do not. Galemba furnishes some evidence to the effect that the former tend to be privileged vis-à-vis the latter. Second, those who do take part in the contraband economy benefit unequally. A case in point is that the contraband economy exacerbates existing class hierarchies. For example, while Tito, one of Galemba's main informants, often helps poor family members and provides employment, residents know and understand that the majority of resources and networks are concentrated within his nuclear family. Moreover, Tito's children enjoy material advantages that prepare them for later success in not only illegal activities but also in the formal economy, because they are able to attend above-average high schools and universities (Galemba, 2012b, p. 12). This is a typical case of the social mechanism of opportunity hoarding. It is a form of social closure in the sense of privilege as a means to increase the opportunities for one's own group, be it based on ethnic, religious, kinship, professional or other grounds (Tilly, 1998, pp. 147-169). This finding indicates that the extra-legal economic practices sharpen and legitimize class differences between residents. It does not question but reinforces social inequalities by weaving together drivers of trucks; border middlemen who organize the transport of goods such as corn, sugar and coffee from Guatemala to Mexico and cement blocks in the opposite direction; and larger-scale smugglers.

Indeed, the very social embeddedness of economic practices at the border in community and kinship ties and in formal economic activities makes it hard to maintain rigid distinctions between legal and illegal, at least from the point of view of the residents involved. Also, it provides key capacities to those who have otherwise little access to employment (cf. Nordstrom, 2007). By implication, it is impossible to maintain the allegedly clear-cut distinction between altruism and profit orientation. Altruism in the form of patronage is one of the main foundations for contraband to yield profit. For example, the patron is expected to cover unexpected costs arising from contraband, such as medical expenses. This means that altruism is an ambiguous mechanism: it may help to entrench inequalities between those participating in contraband, but may also empower the recipients to improve their life chances.

Over the years, the perceptions of legal/illegal and honest/dishonest distinctions have changed, however. The clandestine road connecting Frontera Comalapa, Mexico, and La Democracia, Guatemala, increasingly became a hub for the cocaine trade, whereby some residents became suspicious of what seemed like middlemen's "all-of-a-sudden earnings". In this context, 
Galemba argues that "under circumstances of increasing inequality and secrecy, local terminologies are shifting from 'work' and 'honest business' to 'contraband' and 'smuggling'”' (Galemba 2012b, p. 14).

\subsection{Divide et Impera}

It is obvious that in divide and rule the broker splits ego and alter on purpose in order to reap the benefits. S/he can do so by sowing mistrust or envy. As mentioned above, states themselves may act as divide and rule brokers, and they may do so in colluding with certain types of migrant labour brokers. In the East Asian case, Chinese state agencies directly structure markets for intermediaries (Biao, 2013). For example, when the Chinese state got out of the business of directly linking workers and foreign employers, as in the case of employers in Japan, it conferred primary agency to intermediaries both upstream and downstream. The result was, among others, a downward allocation of liability to the individual migrant-a clear case of hierarchization of control and thus power. Thus, in a group of migrants, the private agents punish all involved if one worker misbehaves; then all are threatened with return to China. Such tight social control of migrants necessitates a constant search for new sources in order to avoid networks of migrants who might try to escape the cage. Migration brokers benefitted from capitalizing on would-be migrants' instrumentalist agendas and the latter's faith in the central state for their ultimate security. The cost for the intermediaries was to experience blame and punishment, rightly or wrongly, whenever the state regarded it as necessary. In a way, one could interpret this case as one of dual brokerage: both the Chinese state and brokers in China benefit from their control over both workers and brokers further down the ladder who are closer to the workers.

Brokers may not only benefit from tensions and maintain them, as in the tertius gaudens type, but consciously create tensions between the two other parties on purpose. A case in point is middlemen in the usedcar business in Cotonou. These démarcheurs in secondhand car markets try to prevent buyers and sellers from creating dependable market relations by skillfully manipulating information to their own advantage (Beuving, 2013, p. 3). Contrary to a common understanding of brokerage, Beuving's case study illustrates that démarcheurs do not corroborate economic functionality in the sense of easing information flows between buyers and sellers: "Hence, in Cotonou there appears to be a need for dependable market information, but at the same time it is impossible to get it. It will be shown how démarcheurs capitalize on this ambivalence and in this way carve out a niche in the market for themselves" (Beuving, 2013, p. 4). Beuving shows further how these intermediaries try to create discontinuities by preventing buyers and sellers from creating dependable market relations, and by skillfully manipulating information to their own advantage. In short, brokers make information scarce, which is rather paradoxical because the information these brokers try to make scarce is exactly what they need themselves to do business. Brokers increase transaction costs between buyers and sellers of cars by threatening revenge: sellers may face negative repercussions if they do not involve the démarcheurs, e.g. demolition of cars during the night (Beuving, 2013, p. 12). The main point is that the démarcheurs seek to create a "nuisance value" by impacting upon car sellers so that the latter surrender and collaborate in sharing the profit with the brokers. Overall, it is a case of brokers dominating buyers and sellers.

To understand that brokers are not necessarily the most powerful party in a triad and are in fact quite vulnerable at times, one has only to think of what have been called middleman minorities. At the height of European colonialism, it was the colonial powers who used brokers as a means to divide and rule over colonized peoples, mainly in Africa and Asia. Well-known examples of these middleman minorities are South Asians who were employed by the British colonial power in East or South Africa as employees in the local administration. Middleman minorities have occupied niches which were unattractive to local entrepreneurs - the Chinese in California, Australia, and Canada in the second half of the nineteenth century who specialized in trades such as laundry shops, tobacco shops and other services, or Indian bureaucrats in African states such as Uganda, brought in by the British colonial authorities during the nineteenth century. Middleman minorities fulfilled specific functions not only economically, such as servicing unattractive niches in service markets, but also politically, for example, by staffing the colonial administrations. In this capacity there were always doubts about whether they could be trusted (Bonacich, 1973). After all, middleman minorities conceived of themselves not as immigrants but as sojourners, that is, temporary residents. And when settlement became more or less permanent, they continued to bear the status of aliens. This also meant exclusion from the political system-at the very least from the formal channels of political claim-making and authority. The vulnerable role of brokers could be seen in the Chinese Exclusion Act in the US which effectively blocked regularized channels of Chinese migration from the early 1880s until the 1940s. The example of the mass expulsion of persons of Indian descent under the dictatorship of Idi Amin in Uganda during the 1970s suggests that their (former) intermediary position between the autochthonous groups and the colonial power made them easy targets for scapegoating.

Although power as a source of social inequalities is by no means restricted to the formal political realm of electoral policies and bureaucratic policies, political 
brokerage is a primary illustration of brokers' vulnerabilities. While middleman minorities are, as ethnic minorities, an obvious target for cultural, political and economic exclusion, there are also more hidden forms of vulnerability among brokers. In a case study on political brokerage as a complex, provisional and contested phenomenon in a Recife slum in Brazil, Koster (2012, p. 480) shows that brokers have to deal with the distinct interests of patrons and clients, as well as with the diverging and ambivalent views the latter have of electoral politics, the patrons and the brokers. Clearly, political brokerage has been a persistent feature of the workings of Brazilian politics in distributing valued goods in exchange for political support in the form of votes. Clientelist politics explain the existence of brokers by the benefits they bring for clients, patrons and for the brokers themselves. It is important to note, however, that the brokers' position not only implies power, as they set the terms for exchanges, but also vulnerability. Mediating between voters and party bosses, for example, brokers risk losing the confidence of their patrons and their clients if they work for several patrons (Koster, 2012, p. 482).

\section{Conclusion}

By employing brokerage as a social mechanism, we can see that it is a crucial part of the functioning of what are called migrant or migration networks, groups and associations. The ubiquitous reference of migration research to migrant or migration networks as an answer to account for the dynamics of migration and for consequences such as the reproduction of old and the production of new (in)equalities is superficial. Instead, the brokerage mechanism indeed provides insight into a range of options and alternatives otherwise unseen. In particular, a focus on brokerage allows us to see the constraining and enabling forces and agents' efforts to deal with them. This is true not only for migrants involved in geographical and social mobility but, thinking reflexively, also for social scientists who analyse brokerage. When analysing concrete cases, the typology with the three types of brokerage-partisan arbitration, tertius gaudens and divide et impera yields a couple of typical sub-mechanisms which are operative in brokerage and relevant for the production of (in)equalities. Of the three types of brokerage discussed, partisan arbitration carries the highest potential for producing equalities instead of inequalities. This outcome is contingent on clear advocacy along norms of equality. Yet one should be careful equating partisan arbitration solely with equality-producing effects since unintended effects abound. For example, migrant advocacy organizations are necessarily selective in which categories of migrants they support. The question thus is rather "Equality for whom?"

What needs to be fleshed out in future work is how brokerage as a social mechanism operates in different contexts, synchronically (across states or organizations) and diachronically (across historical epochs). Histories of migration have convincingly shown the different forms long-distance migration has taken over the centuries. Questions arise, such as: did the invention of strict border controls in the $19^{\text {th }}$ century and the expansion of brokerage in international migration go hand in hand? How do the Atlantic, Pacific or even Asian/Siberian migration systems of the nineteenth century differ from contemporary movements, and what are the consequences for the operation of brokerage? And what are the structural differences across different types of mobility for brokerage-such as movement of international students, expatriates, posted workers, tourists, classical labour migration, forced migration, or circular migration? Such an analysis will certainly provide more sub-mechanisms conducive for the (re)production of (in)equalities and, above all, an opportunity for a taxonomy of brokerage.

\section{Acknowledgements}

The author would like to thank Başak Bilecen for helpful suggestions.

\section{Conflict of Interests}

The author declares no conflict of interest.

\section{References}

Abella, M. (1995). Asian migrant and contract workers in the Middle East. In R. Cohen (Ed.), Cambridge survey of world migration (pp. 418-423). Cambridge: Cambridge University Press.

Alpes, M. J. (2013a). Social protection, migration control and transnational family life: The case of migrant families and welfare hotels in Paris. Paper presented at the symposium Brokering Human Security: Access at Times of Heightened Migration Control, Paris, Centre de Recherche Internationales (CERI), 2-3 September 2013.

Alpes, M. J. (2013b). Migration brokerage, illegality, and the state: The case of two NGOs in Anglophone Cameroon (DIIS Working Paper Series). Copenhagen: Danish Institute for International Studies (DIIS).

Alpes, M. J. (2013c). Law and credibility of migration brokers: The case of emigration dynamics in Cameroon (IMI Working Papers Series, no 2013, No. 80). Oxford: International Migration Institute (IMI), University of Oxford. Retrieved from http://www.imi. ox.ac.uk/publications/working-papers/wp-80-2013

Bales, K. (1999). Disposable people: New slavery in the global economy. Berkeley, CA: University of California Press.

Barron, P., Bory, A., Chauvin, S., Jounin, N., \& Tourette, L. 
(2011). On bosse ici, on reste ici! La grève des sanspapiers: Une aventure inédite. Paris: La Découverte.

Beuving, J. (2013). Playing the Information Game: Démarcheurs in the second-hand car markets in Cotonou, Bénin. Social Anthropology, 21(1), 2-22.

Biao, X. (2007). Gobal "body shopping": An Indian labour system in the information technology industry. Princeton, NJ: Princeton University Press.

Biao, X. (2013). The intermediary trap: international labour recruitment, transnational governance and state-citizen relations in china. Asia Colloquia Papers, 3(1). Retrieved from http://www.yorku.ca/ycar/ Publications/Asia_Colloquia_Papers_Xiang.pdf

Bilecen, B., \& Faist, T. (2014). International doctoral students as knowledge brokers: Reciprocity, trust and solidarity in transnational networks. Global Networks, forthcoming.

Bonacich, E. (1973). A theory of middleman minorities. American Sociological Review, 38(5), 583-594.

Burt, R. L. (1992). Structural holes: The social structure of competition. Cambridge, MA: Harvard University Press.

Bush, M. L. (2000). Servitude in modern times. Cambridge: Polity.

De Sardan, O. (2005). Anthropology and development: Understanding contemporary social change. London: ZED Books.

De Wenden, C. (2010). La question migratoire au XXIe siècle. Migrants, réfugiés et relations internationales. Paris: Presses de Sciences Po.

DiMaggio, P., Garip, F. (2012). Network effects and social inequality. Annual Review of Sociology, 38, 93-118.

Falleti, T. G., \& Lynch, J. F. (2009). Context and causal mechanisms in political analysis. Comparative Political Studies, 42(9), 1143-1166.

Feldman, D. (2013). Border communities are not for sale! A "queer" rejection of "border security" in Southern Arizona. Paper presented at the symposium "Brokering Human Security: Access at Times of Heightened Migration Control", Paris, Centre de Recherche Internationales (CERI), 2-3 September 2013.

Ferguson, J. (1999). Expectations of modernity: Myths and meanings of urban life on the Zambian Copperbelt. Berkeley, CA: University of California Press.

Gaibazzi, P. (2013). Visa problem: Certification, kinship and the production of 'ineligibility' in Gambia. Paper presented at the symposium "Brokering Human Security: Access at Times of Heightened Migration Control", Paris, Centre de Recherche Internationales (CERI), 2-3 September 2013.

Galbraith, J. K. (1979). The nature of mass poverty. Cambridge, MA: Harvard University Press.

Galemba, R. (2012a). "The border is our inheritance": Middlemen smugglers, truckers, and configurations of power and profit at the Mexico-Guatemala border. Paper presented at the Conference of the American Anthropology Association.
Galemba, R. (2012b). Taking contraband seriously: Practicing "legitimate work" at the Mexico-Guatemala border. Anthropology of Work Review, 33(1), 3-14.

Gammeltoft-Hansen, T., \& Nyberg Sørensen, N. (Eds.) (2013). The migration industry and the commercialization of international migration. London: Routledge.

Gatti, F. (2011). Bilal. Als Illegaler auf dem Weg nach Europa. Reinbek: Rowohlt.

GCIM. (2005). Migration in an interconnected world: New directions for action. Geneva: Global Commission on International Migration.

Gold, S. J. (2005). Migrant networks: A summary and critique of relational approaches to international migration. In M. Romero \& E. Margolis (Eds.), The Blackwell Companion to Social Inequalities (pp. 257-285). Oxford: Blackwell.

Goldin, I., Cameron, G., \& Balarajan, M. (2011). Exceptional people: How migration shaped our world and will define our future. Princeton, NJ: Princeton University Press.

Gould, R. V., \& Fernandez, R. M. (1989). Structures of mediation: A formal approach to brokerage in transaction networks. Sociological Methodology, 19(1), 89-126.

Granovetter, M. S. (1973). The strength of weak ties. American Journal of Sociology, 78(6), 1360-1380.

Hollifield, J., Martin, P. L., \& Orrenius, P. (Eds.) (2013). Controlling immigration: A global perspective (3d ed.). Stanford, CA: Stanford University Press.

ILO (International Labour Office). (2012). ILO global estimate of forced labour: Results and methodology. Geneva: International Labour Organization.

Jaffe, R. (2013). The hybrid state: Crime and citizenship in urban Jamaica. American Ethnologist, 40(4), 734-748.

Kalir, B., \& Sur, M. (2012). Transnational flows and permissive policies: Ethnographies of human mobilities in Asia. Amsterdam: Amsterdam University Press.

Koster, M. (2012). Mediating and getting "burnt" in the gap: Politics and brokerage in a Recife slum, Brazil. Critique of Anthropology, 32, 479-497.

Kraut, A. M. (1982). The huddled masses: The immigrant in American Society, 1880-1921. Arlington Heights, IL: Harlan Davidson.

Krissman, F. (2005). Sin coyote ni partrón: Why the "migrant network" fails to explain international migration. International Migration Review, 39(1), 4-44.

Kuptsch, C. (Ed.) (2006). Merchants of labour. Geneva: International Labour Organization.

Lindio-McGovern, L. (2013). Globalization, labour export and resistance: a study of filipino migrant workers in global cities. New York: Routledge.

Lindquist, J., Xiang, B., \& Yeoh, B. S. A. (2012). Opening the black box of migration: Brokers, the organization of transnational mobility and the changing political economy in Asia. Pacific Affairs, 85(1), 7-19.

Lippert, R. K. (2005). Sanctuary, Sovereignty and sacrifice: Canadian sanctuary incidents, power, and law. 
Vancouver: University of British Columbia Press.

Lipton, M. (1980). Migration from rural areas of poor countries: The impact of rural productivity and income distribution. World Development, 8(1), 1-24.

Lucassen, J., \& Lucassen, L. (Eds.) (2014). Globalising migration history: The Eurasian experience (16th-21st centuries). Leiden and Boston: Brill.

Massey, D. S., \& Aysa, M. (2005). Social capital and international migration from Latin America. Expert Group Meeting on International Migration and Development in Latin America and the Caribbean, Population Division Department of Economic and Social Affairs, United Nations Secretariat, Mexico City, 21 November 2005.

McAdam, D., Tarrow, S., \& Tilly, C. (2001). Dynamics of contention. New York: Cambridge University Press.

McKeown, A. (2008). Melancholy Order: Asian migration and the globalization of borders. New York: Columbia University Press.

Mckeown, A. (2012). How the box became black: Brokers and the creation of the free migrant. Pacific $A f$ fairs, 85(1), 21-46.

Minghuan, L. (2012). "Playing edge ball": Transnational migration brokerage in China. In B. Kalir \& M. Sur (Eds.), transnational flows and permissive polities: Ethnographies of human mobilities in Asia (pp. 207228). Amsterdam: Amsterdam University Press.

Moch, L. P. (1992). Moving Europeans: Migration in Western Europe since 1650. Bloomington: Indiana University Press.

Morawska, E. (2007). Human trafficking in and out of East Europe. In M. Lee (Ed.), Human smuggling and migration. Devon: Willan Publishing.

Nordstrom, C. (2007). Global outlaws: Crime, money, and power in the contemporary world. Berkeley, CA: University of California Press.

O’Connell Davidson, J. (2013). Troubling freedom: Migration, debt, and modern slavery. Migration studies, 1(2), 176-195.

Oliver, P. (2003). Mechanisms of contention. Mobilization, 8, 122-129.

Passas, N. (1994). Informal value transfer systems and criminal organizations: A study into so-called underground banking networks. The Hague: Ministry of
Security and Justice.

Pécoud, A., \& Geiger, M. (Eds.) (2013). Disciplining the transnational movement of people. London: Routledge.

Polanyi, K. (1944). The great transformation: The political and economic origins of our time. Boston: Beacon Press.

Reddy, G. R., \& Haragopal, G. (1985). The pyraveekar: "The fixer" in rural India. Asian Survey, 25(1), 11481162.

Sanchez, G. (2013). Latina migrant women as facilitators of transnational migration in the US Southwest. Paper presented at the symposium "Brokering Human Security: Access at Times of Heightened Migration Control", Paris, Centre de Recherche Internationales (CERI), 2-3 September 2013.

Silverman, S. F. (1965). Patronage and community-nation relationships in central Italy. Ethnology, 4(2), 172-189.

Simmel, G. (1992). Soziologie. Untersuchungen über die Formen der Vergesellschaftung. Frankfurt a.M.: Suhrkamp.

Spaan, E. (1994). Taikongs and calas: The role of middlemen and brokers in Javanese international migration. International Migration Review, 28(1), 93-113.

Sredanovic, D. (2013). Models of representation, mobilization and turnout: The election of the foreign citizens' council of the province of Bologna. International Migration. doi:10.1111/imig.12130

Therborn, G. (Ed.) (2006). Inequalities of the world: New theoretical frameworks, multiple empirical approaches. London: Verso.

Tilly, C. (1998). Durable inequality. Berkeley, CA: University of California Press.

Van Walsum, S. (2009). Against all odds: How single and divorced migrant mothers were eventually able to claim their right to respect for family life. European Journal of Migration and Law, 11(2), 295-311

Weber, M. (1968). Economy and society. In G. Roth \& C. Wittich (Eds.). Berkeley, CA: University of California Press.

Wolf, E. R. (1956). Aspects of group relations in a complex society: Mexico. American Anthropologist, 58(6), 1065-1078.

\section{About the Author}

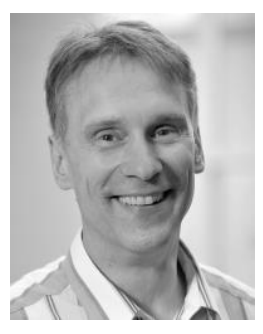

\section{Dr. Thomas Faist}

Dr. Thomas Faist is Professor for Sociology and Dean of the Faculty of Sociology at Bielefeld University, Germany. His fields of interest are transnational relations, citizenship, social policy, development and migration. Thomas Faist is a member of the editorial boards of Ethnic and Racial Studies, Social Problems, South Asian Diaspora, Social Inclusion, Migration and Development and the Pakistan Journal of Social Issues. Books he recently co-published include Beyond Methodological Nationalism: Social Science Research Methodologies in Transition (2012), Transnational Migration (2013), and Disentangling Migration and Climate Change (2013). His current research focuses on the global social question. 